\title{
Climate variability impact on groundwater resources in the Highest Bandama watershed at Tortiya (Northern Côte D'Ivoire)
}

\author{
Soro Tanina Drissa ${ }^{1,}$, , Djè Kouakou Bernard ${ }^{2}$, Ahoussi Kouassi Ernest ${ }^{1}$, Soro Gbombélé ${ }^{1}$, \\ Kouassi Amani Michel ${ }^{3}$, Kouadio Konan Emmanuel ${ }^{1}$, Oga Yéi Marie-Solange ${ }^{1}$, Soro Nagnin ${ }^{1}$ \\ ${ }^{1}$ Laboratoire des Sciences et Techniques de l'Eau et de l'Environnement, UFR des Sciences de la Terre et des Ressources Minières, \\ Université Félix Houphouët Boigny de Cocody, 22 B.P. 582 Abidjan 22, Côte d'Ivoire \\ ${ }^{2}$ Centre universitaire de recherche et d'application en télédétection, UFR des Sciences de la Terre et des Ressources Minières, Université \\ Félix Houphouët Boigny de Cocody, 22 B.P. 582 Abidjan 22, Côte d'Ivoire \\ ${ }^{3}$ Département des Sciences de la Terre et des Ressources Minières, Institut National Polytechnique Félix Houphouët Boigny, BP 1093 \\ Yamoussoukro, Côte d'Ivoire
}

\section{Email address:}

paragafro@yahoo.fr(S. T. Drissa),dje_kbernard2003@yahoo.fr(D. K. Bernard), ahoussi_kouassi@caramail.com(A. K. Ernest), marc_soro@yahoo.fr(S. Gbombélé), michel.a_kouassi@yahoo.fr(K. A. Michel), emmakouadio@hotmail.com(K. K. Emmanuel), oga_oms@yahoo.fr(O.Y. Marie-Solange), soro_nagnin@yahoo.fr(S. Nagnin)

\section{To cite this article:}

Soro Tanina Drissa, Djè Kouakou Bernard, Ahoussi Kouassi Ernest, Soro Gbombélé, Kouassi Amani Michel, Kouadio Konan Emmanuel , Oga Yéi Marie-Solange, Soro Nagnin. Climate Variability Impact on Groundwater Resources in the Highest Bandama Watershed at Tortiya (Northern Côte D'Ivoire). American Journal of Environmental Protection. Vol. 2, No. 4, 2013 , pp. $103-112$. doi: 10.11648/j.ajep.20130204.11

\begin{abstract}
The present study carried out in the Highest Bandama watershed at Tortiya, in the northern of Côte d'Ivoire, aims to evaluate climate variability impact on groundwater resources in order to best management. It is based on rainfall and runoff data exploitation. Thus, application of low-pass filter of Hanning and statistic tests (Pettitt, Lee and Heghinian) shows a rainfall regime modification occurred around the seventies years. This modification reveals a decrease of rainfall between $12 \%$ and $22 \%$ according the stations, with an average of $16.5 \%$. This decrease is very high for runoff (62.5\%) at Tortiya station. The isohyets plots confirm the decrease of rainfall during five decades. Coefficients of depletion obtained by Maillet method become very high (more than $810^{-2} \mathrm{j}^{-1}$ ) after the seventies years. Groundwater recharge decreases with an average efficace infiltration of $212 \mathrm{~mm}$ in decade 1980-1989, and $184 \mathrm{~mm}$ in the decade 1990-1999.
\end{abstract}

Keywords: Climate Variability, Groundwater Resources, The Highest Bandama Watershed at Tortiya, Côte d'Ivoire

\section{Introduction}

Climatic change and its influence on the environment and the society are at the heart of the preoccupation political and scientific present [1]. For a region already vulnerabilised like West Africa, this question is vital. In fact, West African area was unregistered one of the most important drought of twentieth century among the 19701990 years. The dependence of major part of agriculture to rainfall cultures makes it one of region particularly vulnerable to rainfall regime changes. The Highest Bandama watershed at Tortiya in north of Côte d'Ivoire, agricultural region, was very well integrated in the presented situation. In these soudano-sahelian areas, agricultural activities, that represented food guaranteed safety [2] for populations, are developed accordingly water resources with a specific seasonal availability rythm. This is the reason for why the present study evaluates the climate variability impacts on groundwater resources. This attempt will help to best management of basin water resources.

\subsection{Study Area}

The Highest Bandama watershed at Tortiya is an under basin of white Bandama basin. It is located between longitudes $5^{\circ}$ and $6^{\circ} 20^{\prime}$ west, and latitudes $8^{\circ} 40^{\prime}$ and $10^{\circ} 20^{\prime}$ north (figure 1). It stretches on Korhogo, Katiola, Niellé, Tengréla and Boundiali square degree, and covers an area 
estimated to $14,500 \mathrm{~km}^{2}$. The most part of basin area $(86 \%)$ is centered on Korhogo square degree.

In it whole, the basin is a huge plateau characterized by areas surfaces aplaned with altitudes ranges from 300 to 400 meters. However, this monotonous of tray was interrupted by granitic domes presented allure of inselbergs.

The basin was largely drained by the Bandama and its principal tributaries (Solomougou, Lopkoho, Yoréloro, Lafigué, Badénou). Hydrographic network appears like a dense water pattern in rainy seasons (Coulibaly, 1978 in [3]). Network hydrographic pattern has a curvilign tendency, and sometimes rectangular. In Korhogo area, there are several small dams on Bandama affluents for agriculture uses and breeding. Agriculture is the main activity followed by breeding.

The climate is soudano-sahelian type (tropical regime of transition) with two contrasting seasons: one rainy season from May to October, and one drought season from November to April with a rainfall average evaluated to $1230 \mathrm{~mm}$ (period 1950-2000). Runoff regime was traced on this of rainfall. It was distinguished one period of low runoff (lower flow) from November to April, and one period of high runoff (flood) from May to October. The most important flood was unregistered in September with
$300 \mathrm{~m}^{3} / \mathrm{s}$ on $1962-1994$ period.

Average relative humidity varies between 35 and $79 \%$. Insolation values are spread over 160.6 hours (July month) to 273.8 hours (January month).

Average temperature unregistered on 1972-2000 period is $26.6^{\circ} \mathrm{C}$. Netherless, the highest values were obtained during drought season with a pick on March $\left(29.5^{\circ} \mathrm{C}\right)$ and the lowest values during rainy season with minimum on August $\left(24.7^{\circ} \mathrm{C}\right)$ (figure 2).

The basin is constituted in major part of ferralitic soils averagely and strongly desaturated. It was encountered nearly the latest ones, ferralitic complex of soils weakly desaturated and brown-eutroph tropical soils derived from basic rocks [4].

On geological plan, the low intensity of metamorphism allows to distinguish two main groups of formations [5]: originated sedimentary formations, and those originated volcanic and very accessorily eruptive (figure 3 ).

Originated sedimentary rocks are essentially composed of variety schists and mica schists associated to greywacks to form a flysch. Originated volcanic rocks are represented by « rocks » (footrace of amphibolites, albite, chlorite and epidote), in other term, basic volcanic rocks or eventually neutral to which added some basic granular rocks.

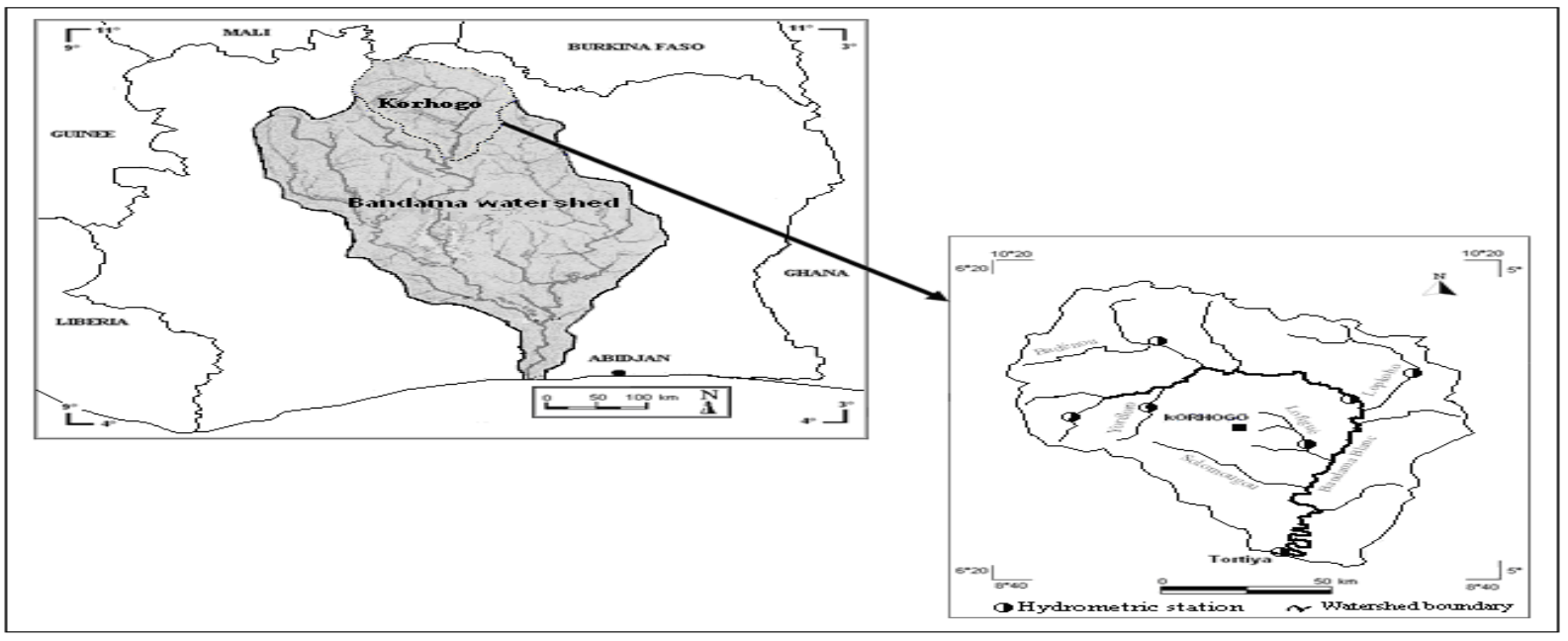

Figure 1. Location map of the study area

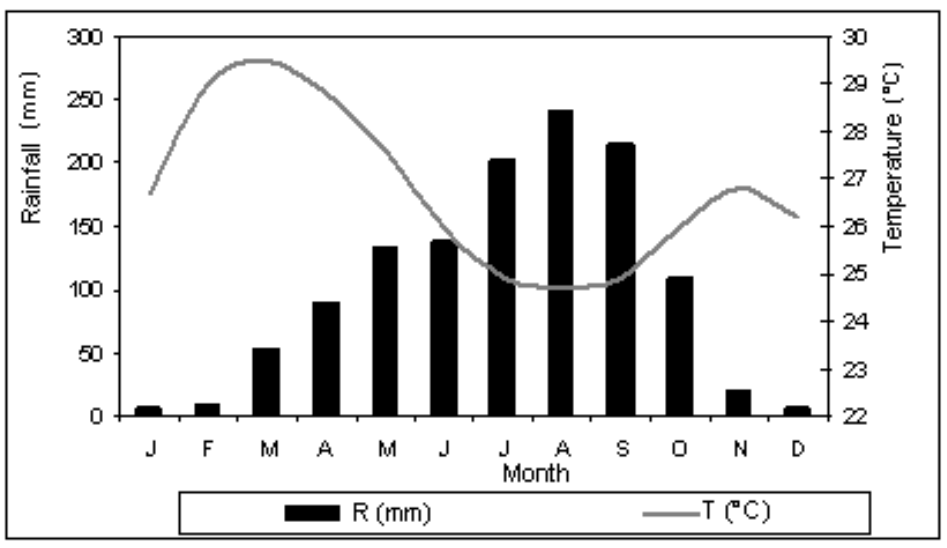

Figure 2. Ombro-thermal diagram of Korhogo synoptic station from 1972 to 2000 


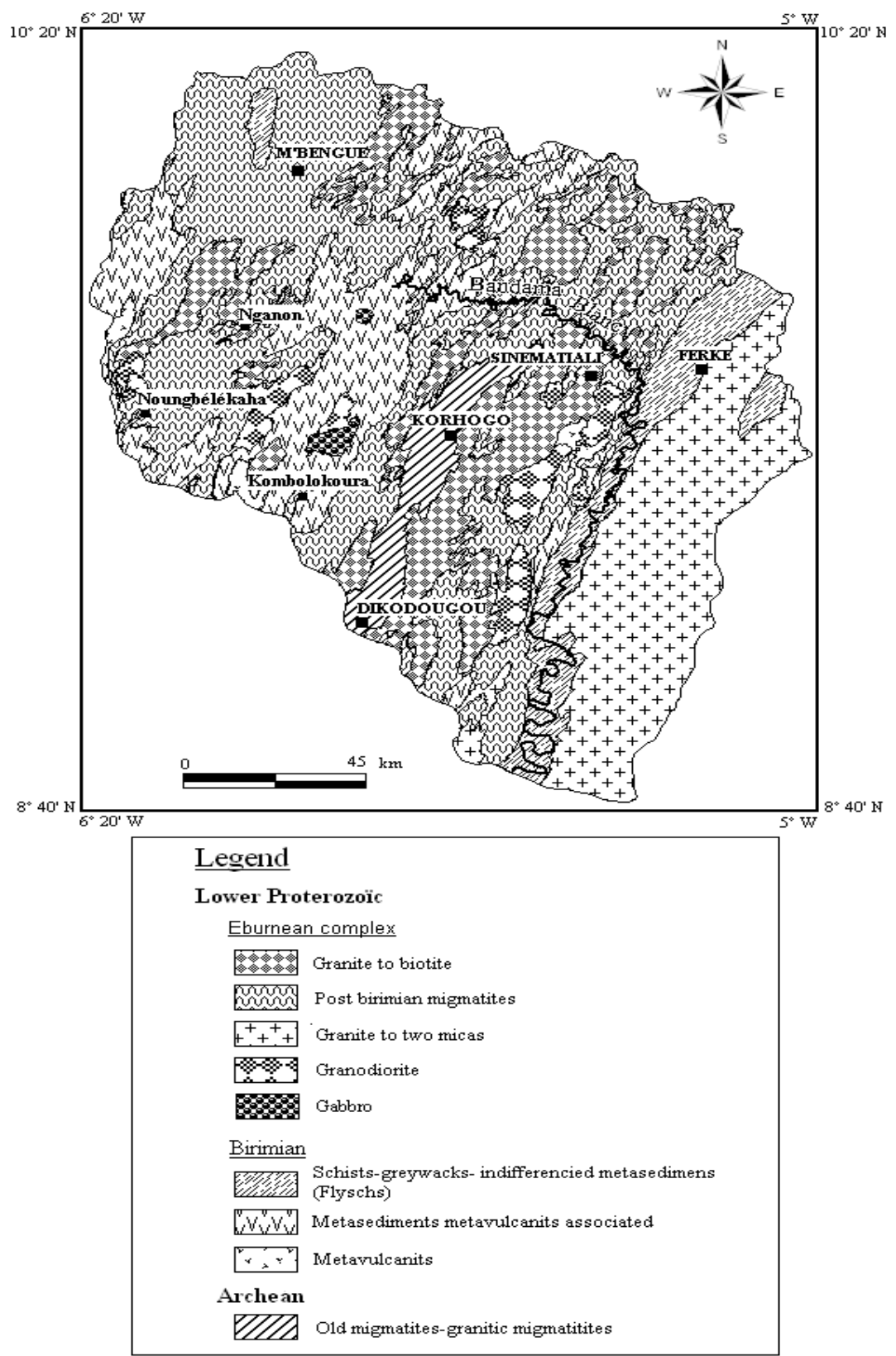

Figure 3. Geological map of the Highest Bandama watershed at Tortiya to scale 1/200000 modified ([6])

\section{Material and Methods}

\subsection{Hydroclimatology}

\subsubsection{Data of Study}

Data consists of daily and monthly rainfall and runoff sets. Rainfall data used are those of Korhogo, Ferkessédougou, Ouangolodougou, Boundiali, Tafiré and Niakaramandougou. There are extended on 1950-2000 period and come from Society of Development and Exploitation Aeroportuary, Aeronautic and Meteorological (SODEXAM) which is the main management on Ivory country. Also, the temperature data from Korhogo synoptic station are been used and extended to the entire watershed.

Data runoff of eight (08) hydrometric stations have been used for study. The last data are given by Hydrology Direction, sub- directory of Human Hydraulics.

Only, hydrometric data of Tortiya station (outlet) have been used for climate variations study because this dataset is the longest (from 1962 to 1994). The data of other stations have been used to fill gap in Tortiya dataset.

\subsubsection{Critic Dataset}

Some gaps have been remarked in chronic data of rainfall and runoff along some years or month of a year. The utilization of these data to raw state is error sources. It is necessary to correct these data before treatment.

\subsection{Rainfall Data Correction}

Rainfall data are good in the whole but have some gaps 
in general for Tafiré and Niakaramandougou posts. We have used double mass (double cumulus) method to fill gap in order to verify dataset homogeneity for all network rainfall stations. The principe of this graphical method consists to verify homogeneity of measured values of the station, to test by correlating those values to reference station values. This operation allows to fill gap lacunas, to test homogeneity, and to critic raw data of rainfall network. This comparison uses, to time step chosen, not individual values observed but their cumulus (Meylan and Musy, 1998 in [7]).

The evaluation of missing data to a station has been determined based on neighbour station data presenting the best correlation coefficient and functioning during the missing month. The most simple formula to fill gap, without major error, or lacunas of dataset, is to replace missing value by a ponderated average which is monthly trend station (Musy and Laglaine, 1992) cited by [7]. In our case, double cumulus test has showed that different rainfalls are homogenous with high strong correlation coefficient. In this case, it can be used neighbour station data. Thus, monthly missing data for Ferkessédougou rainy station along 1981, 1982, 1994 and 1995 years had been filled with Ouangolodougou station data. Data missing for October (1966), May (1967), November and December (1979) and January - February (1980) months at Boundiali station had been reconstituted based on Korhogo airport station data.

$$
x_{(t)}=0.06 x_{(t-2)}+0.25 x_{(t-1)}+0.38 x_{(t)}+0.25 x_{(t+1)}+0.06 x_{(t+2)} \text { for } 3 \leq \mathrm{t} \leq(\mathrm{n}-2)
$$

Where $x_{(t)}$ is total ponderated rainfall of term $\mathrm{t}$, $x_{(t-2)}$ and $x_{(t-1)}$ are total rainfall of two terms immediately preceeding the term $\mathrm{t}$, and $x_{(t)}$ and $x_{(t+1)}$ are total rainfall of two terms following immediately the term $\mathrm{t}$.

Total ponderated rainfall for the two first terms $\left\lfloor x_{(1)}, x_{(2)}\right\rfloor$ of dataset, and the last two terms of set $\left\lfloor x_{(n-1)}, x_{(n)}\right\rfloor$ are calculated using the following expressions ( $\mathrm{n}$ has been the size of set):

$$
\begin{gathered}
X_{(1)}=0.54 x_{(1)}+0.46 x_{(2)} \\
X_{(2)}=0.25 x_{(1)}+0.50 x_{(2)}+0.25 x_{(3)} \\
X_{(n-1)}=0.25 x_{(n-2)}+0.50 x_{(n-1)}+0.25 x_{(n)} \\
X_{(n)}=0.54 x_{(n)}+0.46 x_{(n-1)}
\end{gathered}
$$

The reduced and centered indexes for annual rainfall ponderated level obtained are calculated to distinguish well deficit and excedentary rainfall periods.

Runoff dataset are been submitted to the same calculation procedures like rainfall dataset.

\subsection{Statistical Tests for Detection of Breaks}

In statistical scientific literature, there are several

\subsection{Runoff Data Correction}

In literature, there are several techniques to reconstitute the missing data. In the case of hydrometric stations located on the same hydrographic river (geographic transposition, volume conservation, etc.), it can use analogue proportionality yardsticks. Methods based on linear regression and coefficients (relation rainfall-rainfall or rainfall-runoff, interpost relations) can be use for that (Musy and Higy, 2003 in [8]). In our study, it had been used analogue proportionality yardstick method to reconstitute runoff data of Tortiya station. Different areas of under basins were calculated, and reports had been used. In tropical regimes, runoff flows (dry up flow) are very weak (even zero) and can be replaced for most time, by annual average, without using monthly correlations or daily runoff [9]. This method was used like complement to the first method.

\subsection{Climate Variability Methods Study}

Low- pass filter of Hanning of second order or ponderated average mobile method

A best observation of inter annual fluctuations are obtained by eliminating seasonal variations. In this case, total annual rainfall is ponderated using the following equations' set recommended by [10]:

methods for detection of breaks in time series (Pettitt test, Buishand statistic, and Lee and Heghinian bayesian procedure, Hubert segmentation). In this study, it has been retained Pettitt test, Lee and Heghinian bayesian method for their power and robustness.We used the software Khronostat 1.00 from Institute of Research and Development (IRD), for statistical analysis.

\subsubsection{Pettitt Test}

The Pettitt test [11] is a non-parametric. It derives from Man-Whitney test. Lake of break in time series $\left(\mathrm{X}_{\mathrm{i}}\right)$ of $\mathrm{N}$ sizes constitutes null hypothesis. The application of test supposes that at any time $t$ including between 1 and $\mathrm{N}$, the time series $\left(\mathrm{X}_{\mathrm{i}}\right) \mathrm{i}=1$ to $\mathrm{t}$ and $\mathrm{t}+1$ to $\mathrm{N}$ belong to the same population. The variable to test is the maximum in absolute value of variable variable $U t, N$ defined by:

$$
U_{t, N}=\sum_{i=1}^{t} \sum_{j=t+1}^{N} D_{i j}
$$

where $D_{i j}=\operatorname{sgn}\left(X_{i}-X_{j}\right)$ with $\operatorname{sgn}(X)=1$ if $X>0$; 0 if $X=0$ and -1 if $X<0$.

In the case where null hypothesis is rejected an estimation of break date is given by $\mathrm{t}$ instant defining the maximum in absolute value of variable $U_{t, N}$. 


\subsubsection{Lee and Heghinian Bayesian Method}

Lee and Heghinian bayesian method [12] aims to confirm or unconfirm the hypothesis of average change in time series. Break absence in time series constitutes the null hypothesis. The procedure is based on the following model:

$$
X_{i}= \begin{cases}\mu+\varepsilon_{i} & i=1, \ldots, \tau \\ \mu+\delta+\varepsilon_{i} & i=\tau+1, \ldots, N\end{cases}
$$

where the $\varepsilon_{i}$ are independents and normally distributed, with null average and $\sigma^{2}$ variance.

The $\tau, \mu, \boldsymbol{\delta}$ variables and $\sigma$ are unknown parameters. $\tau$ and $\delta$ represent the break position in time and the change amplitude on average, respectively. The method gives therefore the likehood that break occurs at $\tau$ moment in time series where it was supposed at priori that it is a change at un-determined moment.

\subsection{Averages Variations Calculation}

For hydroclimatic variables which chronologic time series presents a break, it is interesting to calculate average variations of a part of break. According [9], the following formula was used:

$$
D=\frac{\bar{x}_{j}}{\bar{x}_{i}}-1
$$

where $\bar{x}_{j}$ represents the average period after break;

$\bar{x}_{i}$ the average period before break.

\subsection{Isohyets Plots}

Knowing $\mathrm{P}$ rainfall in many points (stations) of $(\mathrm{X} ; \mathrm{Y})$ coordinates, it was extrapolated it on entire study area using Surfer 8.0 software by krijing method. This method allows having an idea on rainfall spatial and temporal evolution on study area.

\subsection{Depletion of Rivers Network and Volumes of Water Mobilized by Study of Aquifers}

\subsubsection{Coefficient of Depletion: Maillet Law and Dichotomic Method}

For coefficient of depletion calculation, it was used Maillet method improved by dichotomic resolution and proposed by [13]. This method is based on Maillet law which expression is the following:

$$
\mathrm{Q}_{\mathrm{t}}=\mathrm{Q}_{0} \mathrm{e}^{-\mathrm{k}}
$$

where:

$\mathrm{Q}_{\mathrm{t}}=$ flow at $\mathrm{t}$ instead given; $\mathrm{Q}_{0}=$ initial flow (flow at the beginning of drying); $\mathrm{k}=$ Maillet drying coefficient.

In dichotomic method, it is estimated that annual recession curb is the expression of ground storage discharge.

The water quantity recovered at jauging station corresponds exclusively to dynamic volumes (V) of water mobilized by all watershed aquifers. The depletion of coefficient $(\mathrm{k})$ is written as:

$$
\frac{e^{-k t}}{k}+\frac{V}{Q_{0}}-\frac{1}{k}=0
$$

\subsubsection{Volumes of Water Mobilized by Aquifers Evaluation}

The mobilized volume by all aquifers is given by the equation:

$$
V_{\text {mobilis } \square}=\int_{0}^{+\infty} Q_{0} e^{-k t} d t=\frac{Q_{0}}{k}
$$

$\mathrm{Q}_{0}$ is expressed in $\left[\mathrm{m}^{3} / \mathrm{s}\right]$ and $\mathrm{k}$ in $\left[\mathrm{j}^{-1}\right] . \mathrm{Q}_{0}$ is multiplied by 86,400 for compatibility of units.

\subsection{Evaluation of Aquifers Recharge}

It is Thornthwaite classic method that was used regarding availability data. Alone excedentary values again called efficace infiltration were retained at water table final of each station during different periods.

\section{Results}

\subsection{Hydroclimatic Variability}

The application of reduced centered index in particularly Hanning second order low-pass filter allows following the watershed climatic fluctuations. There have been marked by succession of humid periods $(\mathrm{PH})$ between 1950 and 1970, and drought periods (PS) after year 1970 for majority rainfall station. For Boundiali rainfall station, one normal period is noted from 1950 to 1975 followed by drought period (1976-2000).

Near these different periods, some trends to reprise were observed from years 1996, 1998 and 1999 respectively for Tafiré, Ferkessédougou and Niakaramandougou stations. The table 1 recaps these results, and figure 4 illustrates the delimitation obtained to Korhogo and Boundiali stations.

Tableau 1. Different trends obtained by application of ponderated average mobiles (1950-2000)

\begin{tabular}{llll}
\hline Station & PH & PS & PN \\
\hline Korhogo & $1950-1970$ & $1971-2000$ & - \\
Ferkessédougou & $\begin{array}{l}1950-1970 ; \\
1998-2000\end{array}$ & $1971-1997$ & - \\
Ouangolodougou & $1950-1970$ & $1971-2000$ & \\
Boundiali & - & $1976-2000$ & $1950-1975$ \\
Tafiré & $1950-1968 ;$ & $1969-1995$ & - \\
Niakaramandougou & $1950-2000$ & & \\
\hline
\end{tabular}

$\mathrm{PH}=$ Humid Period; $\mathrm{PS}=$ Drought period $\mathrm{PN}=$ Normal period 


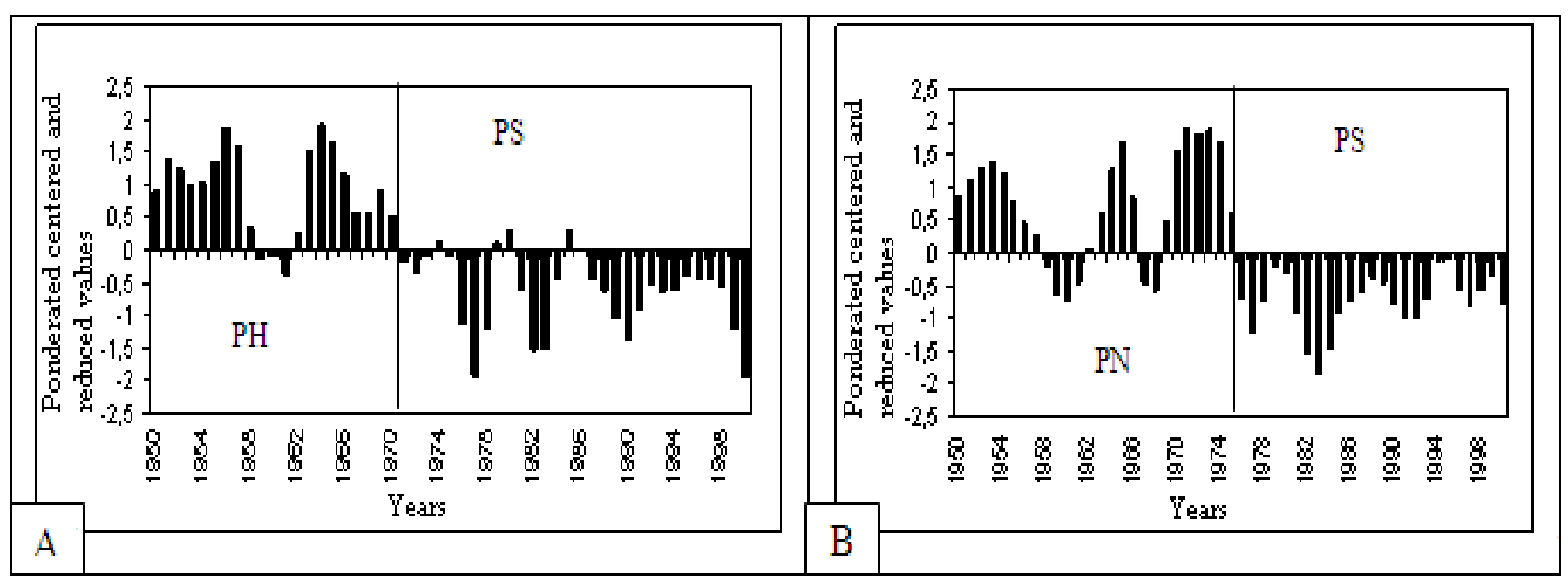

Figure 4. Interannual rainfall evolution with reduced and centered indexes of total annual rainfall ponderated (A) to Korhogo station, and (B) to Boundiali station for 1950-2000 period

The application of break tests has allowed to situate the periods that marks a modification of climate regime in chronological series. The breaks occurred majority between 1968 and 1970 for watershed (table 2). Rainfall deficits have been calculated of a part of break year. The results show that rainfall deficits are situated between

$12 \%$ (Niakaramandougou) and 22\% (Ouangolodougou) with an average of $16.5 \%$ for entire watershed (table 2 ). It is remarked that the most rainfall deficits are enregistrated at Ouangolodougou and Boundiali, and the lowest at Niakaramandougou in South part of watershed.

Table 2. Break and rainfall deficits of watershed stations (1950-2000)

\begin{tabular}{|c|c|c|c|c|}
\hline Station & $\begin{array}{l}\text { Break } \\
\text { year }\end{array}$ & $\begin{array}{l}\text { Average } \\
\text { before } \\
\text { break } \\
(\mathrm{mm})\end{array}$ & $\begin{array}{l}\text { Average } \\
\text { after } \\
\text { break } \\
(\mathrm{mm})\end{array}$ & $\begin{array}{l}\text { Variation } \\
(\%)\end{array}$ \\
\hline Korhogo & 1970 & 1405 & 1218 & -13 \\
\hline Ferkessédougou & 1970 & 1401 & 1161 & -17 \\
\hline Ouangolodougou & 1970 & 1300 & 1011 & -22 \\
\hline Boundiali & 1975 & 1674 & 1299 & -22 \\
\hline Tafiré & 1968 & 1206 & 1047 & -13 \\
\hline Niakaramandougou & 1968 & 1225 & 1072 & -12 \\
\hline
\end{tabular}

As for hydrometric times series, the low-pass filter of Hanning of second order highlight a humid period $(\mathrm{PH})$ from 1962 to 1974 followed by drought period (PS) from 1975 to 1994 . The modules before and after break are 101.6 $\mathrm{m}^{3} / \mathrm{s}$, and $38.1 \mathrm{~m}^{3} / \mathrm{s}$ respectively, with $62.5 \%$ of deficit (table 3).

Table 3. Hydrometric deficit of Tortiya station (1962-1994)

\begin{tabular}{lllll}
\hline Station & Reference & $\begin{array}{l}\text { Annual module } \\
\text { before } \\
\text { break }\left(\mathbf{m}^{3} / \mathbf{s}\right)\end{array}$ & $\begin{array}{l}\text { Annual } \\
\text { module after } \\
\text { break }\left(\mathbf{m}^{3} / \mathbf{s}\right)\end{array}$ & $\begin{array}{l}\text { Variation } \\
(\%)\end{array}$ \\
\hline Tortiya & 1974 & 101.6 & 38.1 & -62.5 \\
\hline
\end{tabular}

\subsection{Spatio-Temporal Variability of Rainfall}

The watershed rainfall spatio-temporal evolution has been studied during five decades (figure 5). The analysis of isohyets values map shows a gradient that is east-west increasing. The decades 1950-1959 and 1960-1969 are the most wetted, as witnessed respectively, with isohyets values of $1530 \mathrm{~mm}$ and $1470 \mathrm{~mm}$ encountered on the watershed. The decade 1970-1979 appears with regular curves of isohyets values. Nevertheless, during this decade, the watershed rainfall is in net decreasing. This decreasing is underlined by $1250 \mathrm{~mm}$ isohyets apparition around Korhogo. The decades 1980-1989 and 1990-1999 are the most deficit. During these decades, it can remark irregular lines of isohyets. The apparition of $1300 \mathrm{~mm}$ isohyet around Boundiali, and downward trend of $1200 \mathrm{~mm}$ isohyet to Korhogo western translates the decrease of rainfall during the last two decades. 

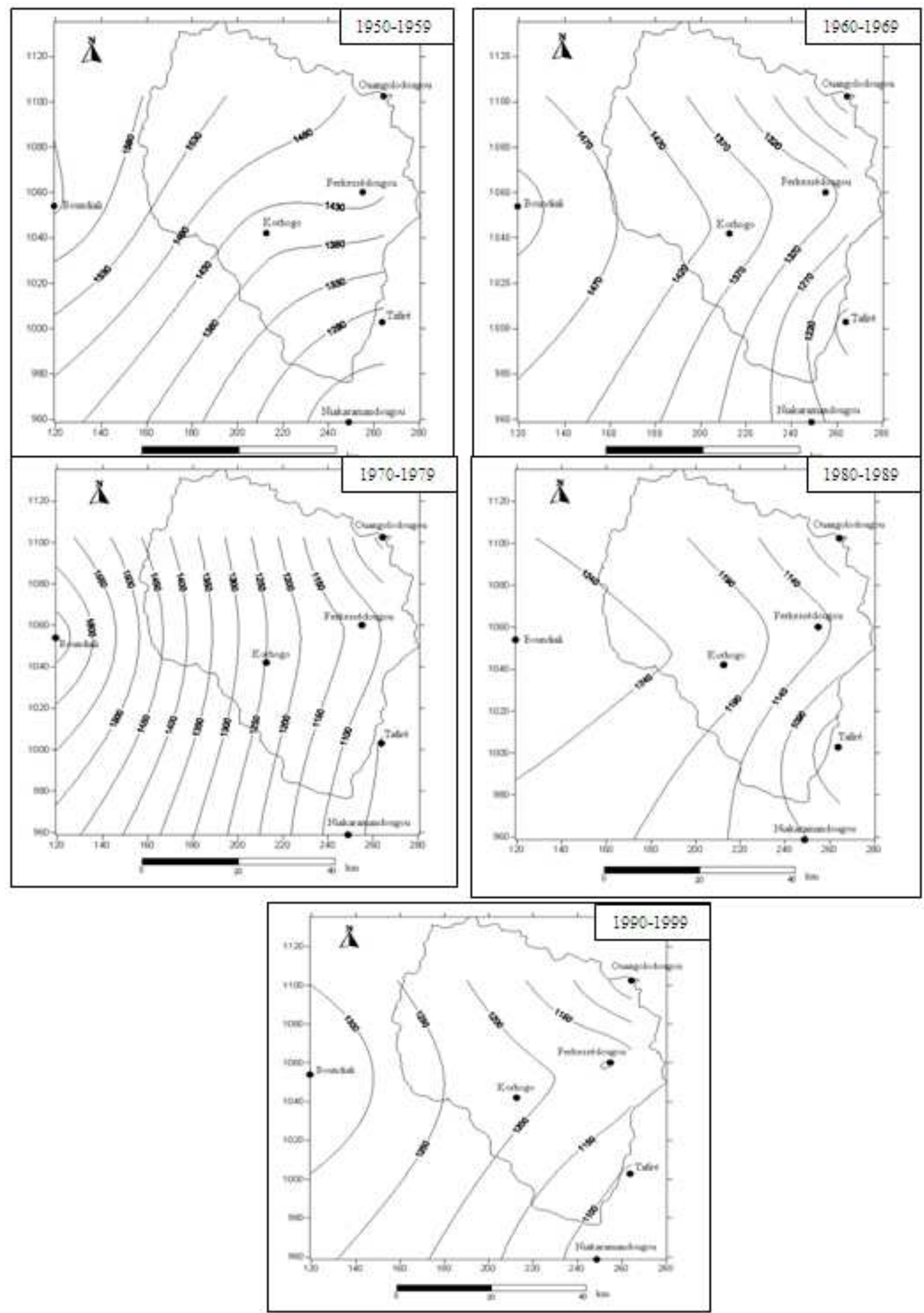

Figure 5. Spatio-temporal evolution of watershed during five decades

\subsection{Depletion of Rivers Network, Volumes of Water} Mobilized by Aquifers and Efficace Infiltrations.

\subsubsection{Variations of Coefficients of Depletion and Volumes of Water Mobilized}

The figure 6 shows the evolution of recession 


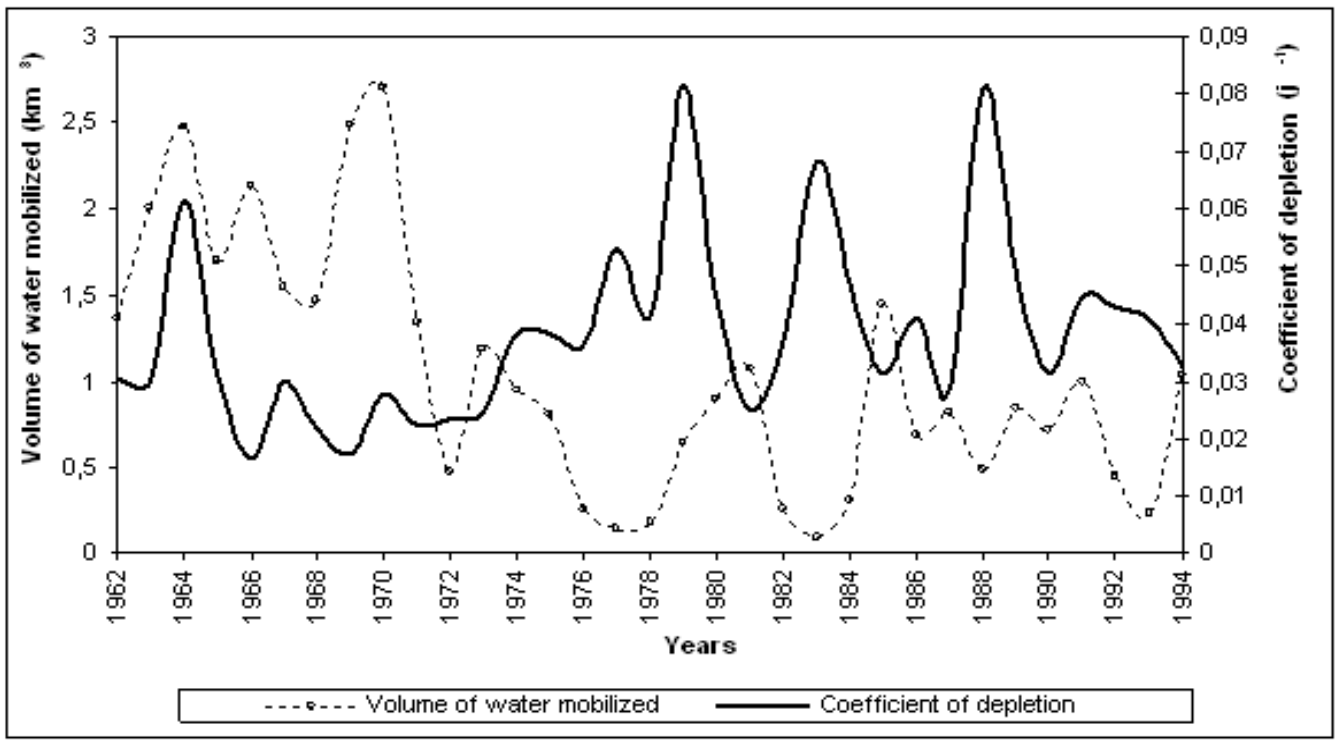

Figure 6. Coefficient of depletion and volume of water mobilized evolution from Bandama watershed in Tortiya (1962-1994)

An important variation of coefficient of depletion and volume of water mobilized resorts through plots analysis of figure 6. The coefficient of depletion values are situated between $1.6310^{-2} \mathrm{j}^{-1}$ and $8.1610^{-2} \mathrm{j}^{-1}$ with an average of $3.8410^{-2} \mathrm{j}^{-1}$. As for volumes of water mobilized, extend from $0.08 \mathrm{~km}^{3}$ to $2.71 \mathrm{~km}^{3}$. It can be remarked that coefficient of depletion and volumes of water mobilized are inversely varied since 1972 . In other term, when coefficient of depletion increases, volume of water mobilized decreases, and vice versa. The highest

values of recession occur after 1970 s most precisely in $1979\left(8.1610^{-2} \mathrm{j}^{-1}\right), 1983\left(6.810^{-2} \mathrm{j}^{-1}\right)$ and $1988\left(8.1210^{-2} \mathrm{j}^{-}\right.$ $\left.{ }^{1}\right)$.

\subsubsection{Evaluation of Aquifers Recharge}

For the most appreciation of recharge variations, the water table has been evaluated for every station on the last two decades 1980-1989 and 1990-1999. Repeted results of rainfall values and efficace infiltration (i.e), called again exceden, are been consigned in the table 4 .

Table 4. Evolution of rainfall and efficacy infiltration of watershed

\begin{tabular}{|c|c|c|c|}
\hline & $1972-2000$ & 1980-1989 & 1990-1999 \\
\hline \multirow{2}{*}{ Station } & $\mathbf{P}(\mathbf{m m})$ & $\mathbf{P}(\mathbf{m m})$ & $\mathbf{P}(\mathbf{m m})$ \\
\hline & i.e.(mm) & i.e. $(\mathrm{mm})$ & i.e.(mm) \\
\hline \multirow{2}{*}{ Korhogo } & 1222 & 1236 & 1211 \\
\hline & 232 & 279 & 219 \\
\hline \multirow{2}{*}{ Ferkessédougou } & 1259 & 1162 & 1203 \\
\hline & 278 & 217 & 249 \\
\hline \multirow{2}{*}{ Ouangolodougou } & 1012 & 1049 & 1012 \\
\hline & 143 & 173 & 137 \\
\hline \multirow{2}{*}{ Boundiali } & 1487 & 1267 & 1351 \\
\hline & 486 & 307 & 368 \\
\hline \multirow{2}{*}{ Tafiré } & 1056 & 999 & 1092 \\
\hline & 110 & 134 & 104 \\
\hline \multirow{2}{*}{ Niakaramandougou } & 1084 & 1094 & 1072 \\
\hline & 83 & 162 & 28 \\
\hline
\end{tabular}

i.e : efficace infiltration
The analysis of table 4 shows accordingly the general way, efficace infiltration and rainfall evoluate in the same direction in watershed during the lastest two decades except Tafiré station. Along these two decades (1980-1989) and (1990-1999), it can be remarked that efficace infiltration is in decrease for Korhogo station (-21.50\%), Ouangolodougou (-20.81\%), Tafiré (-22.39\%), and Niakaramandougou $(-82.72 \%)$. In spite of, for Ferkessédougou and Boundiali stations, it can be unregistered an increase of $(+14.75 \%)$, and $(+19.87 \%)$ respectively.

\section{Discussion}

\subsection{Hydroclimatic Variability of Watershed}

The application of low-pass filter of Hanning for second order allowed to establish different tendencies beyond the hydroclimatic times series. It has been generally marked the alternance of drought and wet periods. The wet (humid) periods are situated before seventies years (1970). The break dates given by statistical tests are ranged between 1968 and 1970, and coincide with the delimitations given by the low- pass filter. These breaks mark thus a modification of rainfall regime. The impact of these modifications of rainfall regime is translated in rainfall deficits ranging from 12 to $22 \%$. These results are in conformity with many other authors' studies in African subregion in whose the present study is noted ([14]; [9]), particularly in Côte d'Ivoire ([15] ; [16] ; [17]) whose were obtained some breaks around seventies years (1970).

For Tortiya outlet hydrometric time series, the breaks occured in 1974. Runoff flow deficit resulted was $62.5 \%$ and represented about three times precipitations deficit. In the same idea [18] underlines a decrease of more than $80 \%$ at Bani to Douna in Mali since 1950, consequences' 
persistence of rainfall decreased since 1970.

Outdoor of West Africa area, climate variability has reached north Africa. In Algeria, the studies of [19] showed annual rainfall decrease overlying $36 \%$ in Mascara area and to west extreme. [20] noted rainfall deficit around 1970 for 44 stations in septentrional Morocco during 1935-2004 period. The pluviometric reduction was $30 \%, 25 \%$ and $15 \%$ respectively for "oriental" region, both the "atlantic southern" and "mountain" sub-regions, and finally both sub-regions "atlantic northern" and "Tangéroise". In the same idea, in Australia, the studies of [21] showed that change and variability led to a several drought on 19962007 period. This drought has lead to water use restriction for more than $90 \%$ of the population, perturbed agricultural production, decreased cattle provision, and lead to failure of some agricultural ranches. Again, some large Australian territory portions had been their surface runoff flow to stop or to decrease.

\subsection{Depletion of Rivers Network, Volumes of Water Mobilized and Recharge of Aquifers}

The study of depletion shows an increasing trend of coefficient of depletion after 1970 s. Some studies carried out by some authors in West Africa whom [22], [18] leads to the same conclusion. This increase of depletion coefficient has been signaled on some Ivorian river by some authors whom [15] at Flampleu station in the west area on Cavally watershed and [23]. In the same ideas, [16] and [24] noted an increase of depletion coefficient in N'zi watershed. For the last author, depletion coefficient ranged between $2.7810^{-2} \mathrm{j}^{-1}$ and $3.9110^{-2} \mathrm{j}^{-1}$ before 1968, year identified like break year in hydrometric time series.

[22] had shown that depletion is considerably accelerated since 70 years leading to fast discharge of aquifers. As proof, this coefficient had passed from $0.02 \mathrm{j}^{-1}$ to $0.04 \mathrm{j}^{-1}$ for Sénégal and the Niger. [25] has also noted this phenomenon on different watersheds, like the Chari in lac Tchad, the Sanaga in Central Africa, for whose the author talks of «hyper depletion». According Darcy law, depletion coefficient is directly proportional to hydraulic conductivity (permeability), to porosity, to river-aquifer exchange and controversly proportional to aquifer dimensions ([22]). The considerably increase of coefficient depletion in drought season corresponded essentially to aquifer reduction and therefore aquifer versant.

The decrease of rainfall was repercuted on aquifers recharge. As proof average efficace infiltration passed from $212 \mathrm{~mm}$ during 1980-1989 to $184.17 \mathrm{~mm}$ for $1990-1999$ decade, in other term a deficit of $13.13 \%$.

\section{Conclusions}

The study of hydroclimatology is useful. It has shown, from a long chronologic rainfall data series, on 1950-2000 a climatic variability marked by wet and drought periods. The statistic tests signaled some breaks that marked rainfall regime modification between 1968 and 1970. The deficits that resulted range between $12 \%$ and $22 \%$ with an average of $16.5 \%$. For hydroclimatic series of Tortiya station (outlet) of watershed, the break has occurred in 1974 with runoff flow deficit estimated to $62.5 \%$, in other terms about the triple of this of rainy.

Isohyets analysis maps during five decades reveals a west-east rainy gradient increasing. The excedentary characteristic of 1950-1959, and 1960-1969 decades is again confirmed by the apparition of $1530 \mathrm{~mm}$ and 1470 $\mathrm{mm}$ isohyets. In opposite, the last two decades 1980-1989 and 1990-1999 are the most deficient. The apparition of $1300 \mathrm{~mm}$ isohyets around Boundiali and the download of $1250 \mathrm{~mm}$ isohyets to Korhogo west confirmed the decrease of rainfall for the last decades. Depletion coefficient values ranged between $1.6310^{-2} \mathrm{j}^{-1}$ and $8.1610^{-2} \mathrm{j}^{-1}$ with an average of $3.8410^{-2} \mathrm{j}^{-1}$. Concerning volumes of water mobilized the values ranged from $0.08 \mathrm{~km}^{3}$ to $2.71 \mathrm{~km}^{3}$. The impact of this rainfall decrease is repercuted on aquifers recharge. As proof, an average of efficace infiltration was passed from $212 \mathrm{~mm}$ (1980-1989) to 184 $\mathrm{mm}(1990-1999)$ that is a $13.13 \%$ deficit.

\section{Acknowledgements}

The authors thank Côte d'Ivoire Hydraulic Human Territorial Director thus his collaborators and particularly, Mr. Akadié, responsible of Sub-Directory Hydrology for hydrometric data (runoff). They addressed again the same thanks to SODEXAM.

\section{References}

[1] Dezetter A., Paturel J. E., Ruelland D., Ardoin-Bardin S., Ferry L., Mahé G., Dieulin C., Servat E., 2008, "Modélisation semi-spatialisée des ressources en eau du fleuve Niger à Koulikoro. Prise en compte des variabilités spatio-temporelles", World Water Congress, 1-4 sept. 2008, Montpellier, France, 111-126.

[2] OMM, 2001, "Le temps, le climat et la sécurité alimentaire", No. 933. Genève : Organisation météorologique mondiale.

[3] Jourda J. P.R., 2005, "Méthodologie d'application des techniques de télédétection et des systèmes d'information géographiques à l'étude des aquifères fissurés d'Afrique de l'Ouest. Concept de l'hydrotechniquespatiale : cas des zones tests de la Côte d'Ivoire", Thèse de Doctorat d'Etat ès Sc. Nat., Université de Cocody, 398 p.

[4] Perraud A., 1971, "Les sols" in "le milieu naturel de la Côte d'Ivoire", Mémoires ORSTOM, pp.269-390.

[5] Arnould M., 1961, "Étude géologique des migmatiques et des granites précambriens du Nord-Est de la Côte d'Ivoire et de la Haute-Volta méridionale", Bulletin de la direction de la géologie et de la prospection minière $\mathrm{n}^{\circ} 1$, Direction de la géologie et de la prospection minière, Abidjan, $175 \mathrm{p}$.

[6] Géomines, 1982, "Inventaire hydrogéologique appliqué à l'hydraulique villageoise", Carte de Korhogo, cahier $\mathrm{n}^{\circ}$ 6, République de Côte d'Ivoire, Ministère des travaux publics et des transports, Direction centrale de l'hydraulique, $44 \mathrm{p}$. 
[7] Riad S., 2003,"Typologie et analyse hydrologique des eaux superficielles à partir de quelques bassins versants représentatifs du Maroc", Thèse de Doctorat de l'Université des Sciences et Technologies de Lille et Université Ibnou Zohr d'Agadir, $154 \mathrm{p}$.

[8] Koffi Y. B., 2007, "Etude du calage, de la validation et des performances des Réseaux de Neurones artificiels à partir des données hydro-climatiques du bassin versant du Bandama Blanc (Côte d'Ivoire)", Thèse de Doctorat Unique, Université de Cocody, 260 p.

[9] Ardoin-Bardin S., 2004, "Variabilité hydroclimatique et impacts sur les ressources en eau de grands bassins hydrographiques en zone soudano-sahélienne", Thèse de Doctorat, Université de Montpellier II, Sciences et Techniques du Languedoc. Spécialité : Mécanique, Génie Mécanique, Génie civil, 437 p.

[10] Assani A. A., 1999, "Analyse de la variabilité temporelle des précipitations (1916-1996) à Lubumbashi (Congo-Kinshasa) en relation avec certains indicateurs de la circulation atmosphérique (oscillation australe) et océanique (El Niño/ la Niña)", Sécheresse, 10, 4, 245-252.

[11] Pettitt A. N., 1979, "A non parametric approach to the change-point problem", Appl. Statist., 28 (2), 126-135.

[12] Lee A. F. S., Heghinian S. M., 1977, "A shift of the mean level in a sequence of independent normal random variables: A Bayesian approach", Technometrics, 19 (4), 503-506

[13] Savané I., Coulibaly K. M., Gioan P., 2003, "Etude comparative de trois méthodes de calcul du coefficient de tarissement des cours d'eau", Sécheresse, Vol. 14, No. 1, 3742.

[14] Paturel J. E., Servat E., Delattre M. O., 1998, "Analyse de séries pluviométriques de longue durée en Afrique de l'Ouest et Centrale non sahélienne dans un contexte de variabilité climatique", Journal des Sciences Hydrologiques, Vol. 43, No.6, pp 937-945.

[15] Savané I., Coulibaly K. M., Gioan P., 2001,"Variabilité climatique et ressources en eaux souterraines dans la région semi-montagneuse de Man", Sécheresse, Vol. 12, No.4, 231237.

[16] Goula B. T. A., Savané I., Konan B., Fadika V., Kouadio B. G., 2006, "Impact de la variabilité climatique sur les ressources hydriques des bassins de N'zo et N'zi en Côte d'Ivoire (Afrique tropicale humide)", VertigO, Vol. 7, $\mathrm{N}^{\circ} 1$, pp. 1-12.

[17] Soro N., Lasm T., Kouadio B. H., Soro G., Ahoussi K. E., 2006, "Variabilité du régime pluviométrique du Sud de la Côte d'Ivoire et son impact sur l'alimentation de la nappe d'Abidjan", Sud Sciences et Technologies , No.14, pp. 30-40.

[18] Mahé G., Olivry J. C., Dessouassi R., Orange D., Bamba F., Servat E., 2000, "Relations eaux de surface-eaux souterraines d'une rivière tropicale au Mali", C. R. Acad. Sci. Paris, Sciences de la Terre et des planètes, 330, p. 689-692.

[19] Meddi H., Meddi M., 2009, "Variabilité des précipitations annuelles du Nord-Ouest de l'Algérie", Sécheresse, Vol. 20, No.1, 57-65.

[20] Sebbar A., Badri W., Fougrach H., Hsaine M., Saloui A., 2011. Etude de la variabilité du régime pluviométrique au Maroc septentrional (1935-2004). Sécheresse, Vol. 22, n 3 , 139-148.

[21] Daniell T. M., 2009, "The implications of a decade of drought in Australia (1996-2007)", Sécheresse, Vol. 20, No.1, p. 171-180.

[22] Briquet J. P., Bamba F., Mahé G., Touré M., Olivry J. C., 1997, "Evolution récente des ressources en eau de l'Afrique atlantique", Revue des Sciences de l'Eau, Vol. 3, p. 321-337.

[23] Saley M. B., 2003, "Système d'informations hydrogéologiques à référence spatiale, discontinuités pseudo-images et cartographies thématiques des ressources en eau de la région semi-montagneuse de Man (Ouest de la Côte d'Ivoire)", Thèse Unique, Université de Cocody, 209 p

[24] Kouassi A. M., 2007, "Caractérisation d'une modification éventuelle de la relation pluie-débit et ses impacts sur les ressources en eau en Afrique de l'Ouest: cas du bassin versant du N'zi (Bandama) en Côte d'Ivoire", Thèse de Doctorat Unique, Université de Cocody, 210 p.

[25] Olivry J.C., 1997, "Long-term effects of rain shortage: the ill rivers of Western and Central Africa", In: FRIEND troisième rapport: 1994-1997. UNESCO-IHP, 1997: 158162. 